[Agr. Biol. Chem., Vol. 36, No. 10, p. $1791 \sim 1796,1972]$

\title{
Purification of Alkaline Proteinase from Aspergillus candidus
}

\author{
By Seiichi Nasuno and Tadahiko OHara \\ Noda Institute for Scientific Research \\ Noda-shi, Chiba-ken
}

Received March 3, 1972

\begin{abstract}
An alkaline proteinase of Aspergillus candidus was purified from wheat bran solid culture by batchwise treatment with Amberlite IRC-50 and sequential chromatography on DEAEcellulose, hydroxylapatite and Sephadex G-100 gel. This purification results in a 18-fold increase of proteolytic activity and the enzyme preparation was homogeneous in sedimentation analysis of the ultracentrifuge and polyacrylamide gel disc electrophoresis. The molecular weight was estimated to be about 23,000 by gel glltration and 22,000 by calculation from the amino acid composition. The enzyme consisted of Lys ${ }_{14}, \mathrm{His}_{4}, \mathrm{Arg}_{3}, \mathrm{Asp}_{25}, \mathrm{Thr}_{15}, \mathrm{Ser}_{23}, \mathrm{Glu}_{15}$, $\mathrm{Pro}_{7}, \mathrm{Gly}_{22}, \mathrm{Ala}_{24}, \mathrm{Met}_{2}, \mathrm{Val}_{16}, \mathrm{Ile}_{11}, \mathrm{Leu}_{10}, \mathrm{Ty}_{6}, \mathrm{Phe}_{7}, \mathrm{Trp}_{2}$ and amide ammonia 14 and did not contain cysteine or cystine.
\end{abstract}

Serine proteases, generally identified by sensitivity to DFP (diisopropylphosphorofluoridate), were the proteolytic enzymes most widely distributed in the microbial world. ${ }^{11}$ Some of these enzymes are also referred to as alkaline proteinases characterized by their alkaline $\mathrm{pH}$ optima. Although a huge number of papers have been published on these enzymes from Aspergillus species, only a few enzymes were isolated in a homogeneous state and characterized in detail. For example, Subramanian and Kalnitsky ${ }^{3}$ isolated aspergillopeptidase A from A. oryzae. Nordwig and Yahn ${ }^{31}$ purified aspergillopeptidase $C$ from the same species. Hayashi et al. ${ }^{4}$ reported the isolation and characterization of alkaline proteinase from $A$. sojae. Similar work has been carried out by Turková et al. ${ }^{51}$ with $A$. flavus, by Ito and Sugiura ${ }^{6}$ with $A$. melleus, and by Danno and Yoshimura with $A$. sydowit ${ }^{7)}$ and $A$. sulphureus. ${ }^{8}$

On the other hand, 20 out of 35 Aspergillus species were found in a previous paper ${ }^{9}$ to produce alkaline proteinases most of which exhibit species-specific mobility in polyacrylamide gel electrophoresis. However, detailed information of these enzymes is confined to the above several examples and enough data are not yet available to unravel the phylogenetic relationship of the proteinases from different species of the genus Aspergillus.

Therefore, it is of much interest to reveal the physico-chemical properties of those enzymes from viewpoints of comparative biochemistry and fungal classification. The present paper aims to describe the purification procedure of alkaline proteinase from $A$. candidus and to charactrize the enzyme by analytical data. Enzymatic properties will be reported in the succeeding paper.

\section{EXPERIMENTAL}

Organism. Aspergillus candidus IAM 2015 was provided by the Culture Collection of the Institute of Applied Microbiology, University of Tokyo.

Chemicals. DEAE-cellulose was obtained from Seikagaku Kogyo Co. Ltd., Tokyo. Blue dextran and Sephadex G-100 were obtained from Pharmacia, Uppsala, Sweden. Amberlite IRC-50 and hydroxylapatite were purchased from Rohm and Haas Co., U.S.A. and Bio-Rad Laboratories, U.S.A., respectively. Pepsin and lysozyme from Nutritional Bio-chemicals 
Corp., U.S.A., trypsin from Worthington Chemicals Co., U.S.A. and $\alpha$-chymotrypsin from Wako Chemicals Co., Tokyo were used as standard proteins for molecular weight determination. Purified alkaline proteinases of $A$. sojae and $A$. oryzae were kindly supplied by Dr. K. Hayashi, Kikkoman Shoyu Co., Ltd. and Mr. T. Nakadai of this institute, respectively. Milk casein (Hammersten grade) used as the substrate in proteinase assay was purchased from Merck Co., Germany. All other chemicals were of guarranteed reagent grade.

Preparation of crude enzyme. A. candidus was grown at $30^{\circ} \mathrm{C}$ for 3 days on $1.2 \mathrm{~kg}$ of wheat bran moistened with $960 \mathrm{ml}$ of tap water. Extraction of the enzyme was performed at $4^{\circ} \mathrm{C}$ overnight with 5 liters of $1 \%$ sodium chloride solution. To the extract about two volumes of cold acetone precooled at $-20^{\circ} \mathrm{C}$ was added to precipitate the enzyme. The precipitates were collected by filtration and dissolved in 1 liter of distilled water. Insoluble materials were removed by centrifuge at $17,000 \mathrm{~g}$ for $30 \mathrm{~min}$. The supernatant solution was dialyzed overnight against three change (each 10 liters) of $5 \mathrm{~mm}$ acetate buffer at $\mathrm{pH}$ 4.6. Unless stated otherwise, further purification was carried out in a cold room at $4^{\circ} \mathrm{C}$.

Enzyme assay. Alkaline proteinase activity was determined by a modification of the Anson's method ${ }^{101}$ as described in a previous paper ${ }^{11}$ and expressed as (PU) units or optical density at $660 \mathrm{~nm}$ in some cases. The concentration of the enzyme protein was spectrophotometrically determined on the basis that the $E_{1 \mathrm{~m} m}^{1 \%}$ at $280 \mathrm{~nm}$ of the enzyme protein was 7.1 which was estimated by dry weight measurement of the purified preparation.

Ultracentrifugal analysis. Sedimentation analysis was performed with a Hitachi model UCA-1 analytical centrifuge at $20^{\circ} \mathrm{C}$ in a single sector cell. The sedimentation coefficient was calculated as described by Schachman ${ }^{121}$ and was corrected at $20^{\circ} \mathrm{C}$ in water.

Electrophoresis. Polyacrylamide gel electrophoresis was carried out by the standard method of Davis. ${ }^{13}$ ) For each run $100 \mu \mathrm{g}$ of the protein sample was employed and electrophoresis at $5 \mathrm{~mA}$ per gel column was performed at $4{ }^{\circ} \mathrm{C}$ for $60 \mathrm{~min}$. Gels were stained with $1 \%$ amido schwartz solution in $7 \%$ acetic acid and destained by repeated washing with $7 \%$ acetic acid.

Determination of amino acid composition. The enzyme protein was hydrolyzed with $6 \mathrm{~N}$ hydrochloric acid at $110^{\circ} \mathrm{C}$ for $24,48,72$ and $100 \mathrm{hr}$ in evacuated sealed tubes. Amino acid analysis was performed with a Hitachi KLA-2 automatic amino acid analyzer. Since serine, threonine and tyrosine were gradually decomposed with increased time of hydrolysis, the analytical values for these amino acids were obtained by extrapolation of the data at the above periods to zero hr of hydrolysis. Tryptophan content was calculated from the ultraviolet absorption of the enzyme dissolved in $0.1 \mathrm{~N}$ sodium hydroxide solution. ${ }^{14}$ The determination of amide ammonia was performed by the Conway's micro-diffusion method ${ }^{15}$ after the treatment according to the Bailey's method. ${ }^{16)}$

Estimation of molecular weight. The molecular weight of the alkaline proteinase of $A$. candidus was estimated by Whitaker's method ${ }^{17 /}$ using Sephadex G-100 column equilibrated with $0.1 \mathrm{~m}$ sodium acetate buffer at $\mathrm{pH} 6.0$. The void volume of the column was measured with blue dextran. Pepsin (M. W. 35,000), a-chymotrypsin (M. W. 25,200), trypsin (M.W. 23,300) and lysozyme (M. W. 14,307) were used as marker proteins.

\section{RESULTS}

\section{Purification of alkaline proteinase}

Batchwise treatment with Amberlite IRC-50. To crude enzyme solution adjusted to $\mathrm{pH} 4.8$ about $300 \mathrm{ml}$ of Amberlite IRC-50 equilibrated with $0.01 \mathrm{M}$ acetate buffer at $\mathrm{pH} 4.8$ was added and frequently agitated for $3 \mathrm{hr}$. Then the enzyme protein was eluted with $500 \mathrm{ml}$ of $0.2 \mathrm{M}$ phosphate buffer at $\mathrm{pH} 7.5$ and dialyzed against five changes (each 2 liters) of $0.01 \mathrm{M}$ phosphate buffer at pH 7.5 for $36 \mathrm{hr}$.

Fractionation on DEAE cellulose. The dialyzed enzyme preparation was applied to a column of DEAE-cellulose equilibrated with the same buffer as dialyzing solution. The column was washed with 1.7 liter of the same buffer and subsequently eluted with a linear gradient of sodium chloride increasing from zero to $0.2 \mathrm{M}$ in 1.4 liter of the same buffer. This procedure separated alkaline proteinase from most of non-enzymatic proteins and colored substances. The peak of the enzyme protein was found at $0.07 \mathrm{M}$ of sodium chloride 
concentration (Fig. 1). The fractions indicated by the bracket in Fig. 1 were pooled and dialyzed overnight against $0.01 \mathrm{M}$ phosphate buffer at $\mathrm{pH} 7.0$.

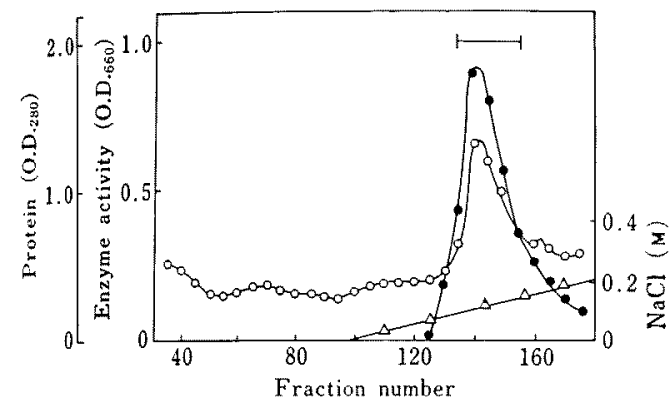

Fig. 1. Separation of Aspergillus candidus Alkaline Proteinase on a DEAE-cellulose Column.

The column $(4 \times 40 \mathrm{~cm})$ was washed and eluted at a flow rate of $60 \mathrm{ml} / \mathrm{hr}$ in $7 \mathrm{ml}$ fractions. $0-0$ Proteins, Enzyme activity, $\triangle-\triangle \mathrm{NaCl}$ concentration.

Fractionation on hydroxylapatite. The above dialyzed sample was applied to a column of hydroxylapatite. The column was fractionated stepwisely with $0.01,0.04$ and $0.06 \mathrm{M}$ phosphate buffer at pH 7.0. Alkaline proteinase activity was eluted with $0.04 \mathrm{M}$ buffer (Fig. 2). The enzyme fractions were collected and concentrated in a collodion bag.

Gel filtration through Sephadex G-100. The concentrated sample was fractionated on a column of Sephadex G-100 equilibrated with $0.01 \mathrm{M}$ ammonium acetate buffer at $\mathrm{pH} 7.0$ containing $1 \mathrm{~mm}$ calcium acetate. Figure 3 shows the good correspondence between enzyme activity and the protein profile. After dialysis against water, the peak fractions were lyophilyzed and used as the purified enzyme for further experiments. Table I summarizes the purification procedure and shows about 18-fold increase of specific activity.

Characterization of alkaline proteinase Sedimentation coefficient. The purity of

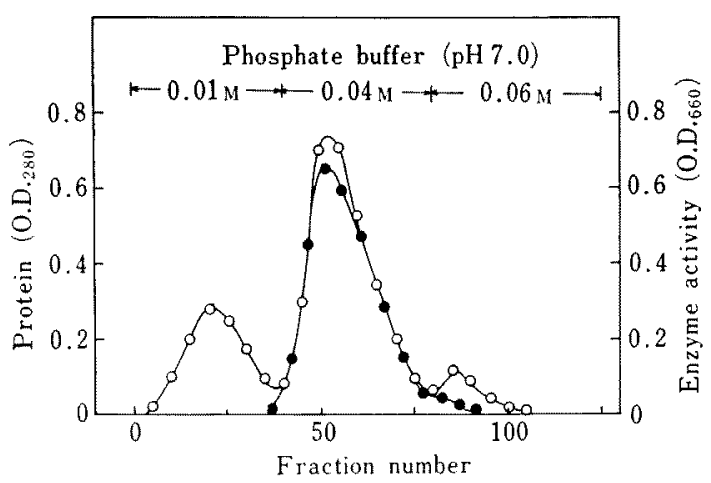

Fig. 2. Chromatography of A. candidus Alkaline Proteinase on Hydroxylapatite.

The column $(3 \therefore 15 \mathrm{~cm})$ was eluted stepwisely at a flow rate of $12 \mathrm{~m} / \mathrm{hr}$ in $10 \mathrm{ml}$ fractions. $0-0$ Protein, - Enzyme activity.

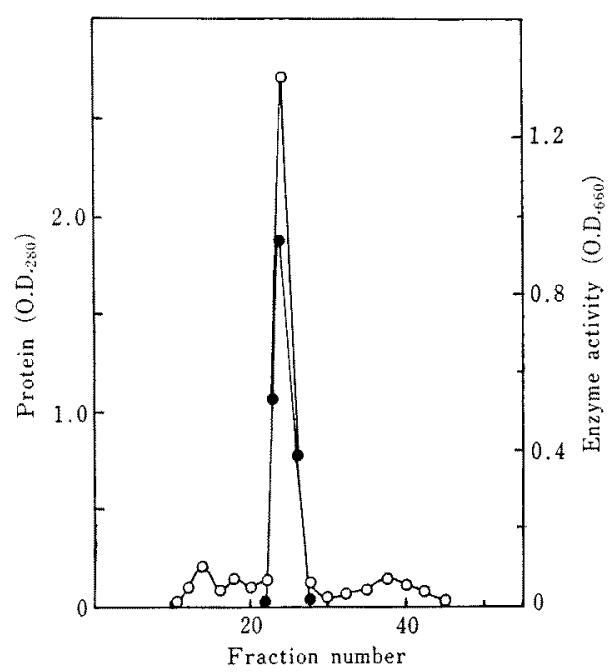

Fig. 3. Sephadex G-100 Elution Pattern of $A$. candidus Alkaline Proteinase.

The column $(2 \times 120 \mathrm{~cm})$ was eluted at a flow rate of $7 \mathrm{ml} / \mathrm{hr}$ in $10 \mathrm{ml}$ fractions. $0-0$ Protein, - Enzyme activity.

the final enzyme preparation was examined by ultracentrifugal analysis. A single protein peak was found during the ultracentrifugal run as shown in Fig. 4. The sedimentation coefficient, $S_{20}^{w}$, of $A$. candidus alkaline proteinase ( $1 \%$ solution) was calculated to be 


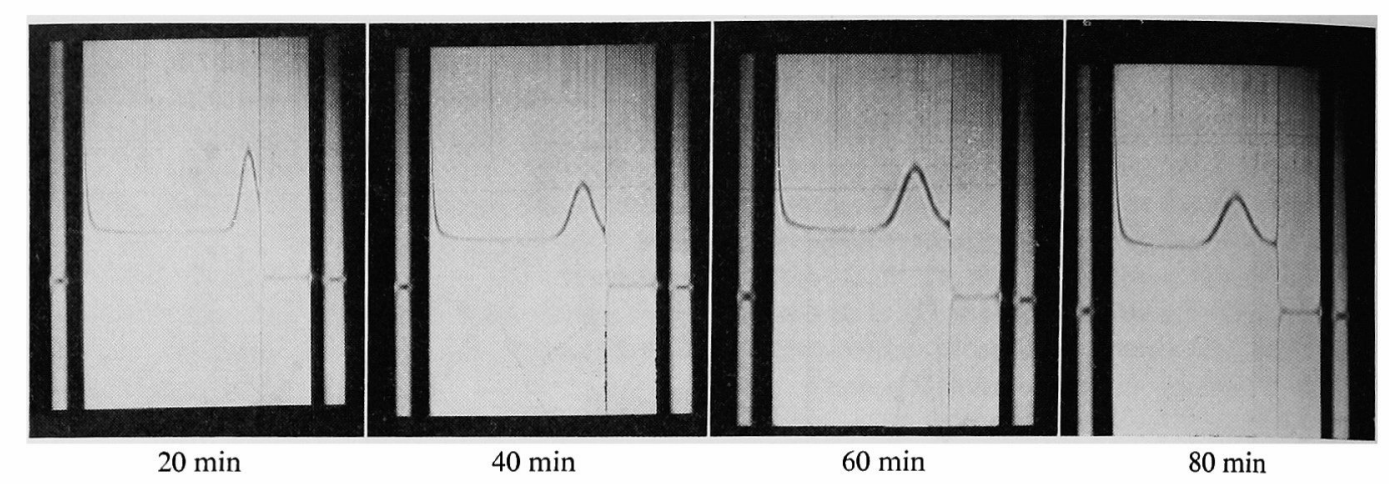

Fig. 4. Sedimentation Patterns of A. candidus Alkaline Proteinase.

The sample was $1 \%$ solution of the enzyme in $0.01 \mathrm{M}$ phosphate buffer $(\mathrm{pH} 7.0)$ containing $0.1 \mathrm{M} \mathrm{NaCl}$. The photographs were taken at the indicated time after reaching the full speed $(55,430 \mathrm{rpm})$.

Table I. Purification of $A$. candidus Alkaline Proteinase

\begin{tabular}{|c|c|c|c|c|c|}
\hline Procedure & $\begin{array}{l}\text { Volume } \\
(\mathrm{ml})\end{array}$ & $\begin{array}{c}\text { Total } \\
\text { activity } \\
\left(\mathrm{PU} \times 10^{3}\right)\end{array}$ & $\begin{array}{l}\text { Total } \\
\text { protein } \\
(\mathrm{mg})\end{array}$ & $\begin{array}{c}\text { Specific } \\
\text { activity } \\
\text { (PU/mg protein) }\end{array}$ & $\begin{array}{c}\text { Recovery } \\
(\%)\end{array}$ \\
\hline Crude enzyme & 1,100 & 1,172 & 33,011 & 35.5 & 100 \\
\hline $\begin{array}{l}\text { Amberlite IRC-50 } \\
\text { treatment }\end{array}$ & 580 & 410 & 7,694 & 51.5 & 35 \\
\hline $\begin{array}{l}\text { DEAE-cellulose } \\
\text { chromatography }\end{array}$ & 350 & 246 & 579 & 450 & 21 \\
\hline $\begin{array}{l}\text { Hydroxylapatite } \\
\text { chromatography }\end{array}$ & 380 & 141 & 251 & 560 & 12 \\
\hline $\begin{array}{l}\text { Sephadex } G-100 \\
\text { chromatography }\end{array}$ & 65 & 94 & 150 & 625 & 8 \\
\hline
\end{tabular}

$3.0 \mathrm{~S}$ from sedimentation velocity at 55,430 rpm and the partial specific volume $(0.70)$ of the enzyme molecule.

Electrophoresis. The purity of the enzyme preparation was also investigated by disc electrophoresis. A single protein band was observed in polyacrylamide gel electrophoresis at $\mathrm{pH} 9.4$ as photographed in Fig. 5-C. The electrophoretic mobility of the alkaline proteinase from $A$. candidus was distinctively different from that from $A$. sojae or A. oryzae (Fig. 5).

Estimation of molecular weight. The determination of the molecular weight was performed by gel filtration though Sephadex
G-100 column. Figure 6 shows the plots of the elution volumes versus the logarithms of the known molecular weights of standard proteins. The molecular weight of $A$. candidus alkaline proteinase was estimated to be 23,000 by this method.

Amino acid composition. The results of amino acid analysis of $A$. candidus enzyme were shown in Table II with those of some other Aspergillus alkaline proteinases. Based on amino acid analysis, the molecular weight of the alkaline proteinase of $A$. candidus was calculated to be about 22,000. Both cysteine and cystine were absent in its amino acid pattern. On the other hand, a content of aspartic acid, alanine, serine and glycine was 
Table II. Amino Acid Composition of Alkaline Proteinase from SOME Aspergillus SPECIES

\begin{tabular}{|c|c|c|c|c|c|}
\hline Amino acid & A. candidus & A. sojae $^{4)}$ & A. oryzae $e^{2\}}$ & A. favus $^{5}$ & A. sulphureus ${ }^{81}$ \\
\hline Lysine & 14 & 12 & $11 \sim 12$ & 11 & 12 \\
\hline Histidine & 7 & 4 & 4 & $3 \sim 4$ & 5 \\
\hline Arginine & 3 & 3 & 2 & 2 & 4 \\
\hline Aspartic acid & 25 & 27 & 21 & 21 & 27 \\
\hline Threonine & 15 & 16 & 11 & 11 & 19 \\
\hline Serine & 23 & 25 & 19 & 20 & 20 \\
\hline Glutamic acid & 15 & 16 & 12 & $12 \sim 13$ & 12 \\
\hline Proline & 7 & 6 & 4 & $4 \sim 5$ & 5 \\
\hline Glycine & 22 & 24 & 19 & 20 & 31 \\
\hline Alanine & 24 & 28 & 23 & 23 & 31 \\
\hline Half cystine & 0 & 0 & 0 & 0 & 0 \\
\hline Methionine & 2 & 2 & 0 & 1 & 0 \\
\hline Valine & 16 & 16 & 15 & 15 & 21 \\
\hline Isoleucine & 11 & 12 & $9 \sim 10$ & $9 \sim 10$ & 10 \\
\hline Tyrosine & 6 & 7 & 5 & 5 & 7 \\
\hline Phenylalanine & 7 & 6 & 5 & 5 & 5 \\
\hline Tryptophan & 2 & 2 & 2 & 2 & 2 \\
\hline Amide ammonia & 14 & 18 & 15 & 17 & 18 \\
\hline
\end{tabular}

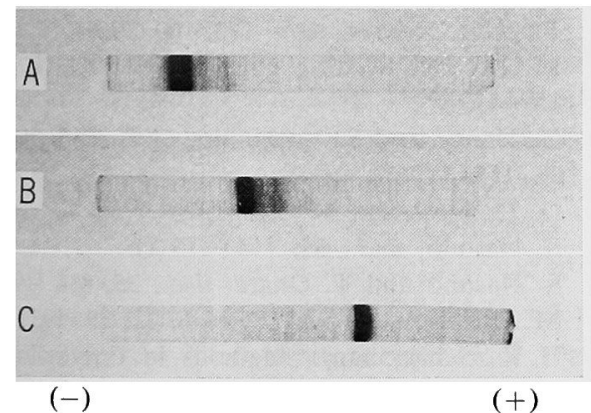

Fig. 5. Polyacrylamide Gel Electrophoresis of Alkaline Proteinases of A. oryzae (A), A. sojae (B) and A. candidus (C).

relatively high.

\section{DISCUSSION}

Aspergillus candidus produces a large amount of alkaline proteinase in wheat bran solid culture. This enzyme migrates 3 to 4 times as fast as alkaline proteinase of $A$. oryzae does in polyacrylamide gel electrophoresis and shows the fastest electrophoretic mobility of all other alkaline proteinases of 20 different

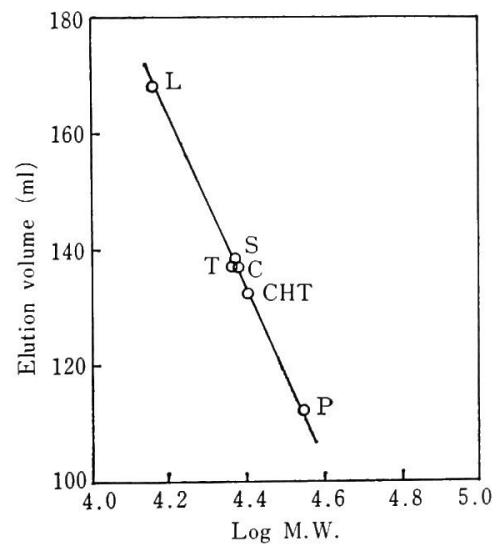

FIG. 6. Estimation of Molecular Weight by Sephadex G-100 Gel Filtration.

L: Lysozyme, $\mathrm{S}: A$. sojae alkaline proteinase, $\mathrm{T}$ : Trypsin, ${ }^{\mathrm{C}} \mathrm{C}$ A. candidus alkaline proteinase, CHT: $\alpha$-Chymotrypsin, P: Pepsin.

\section{Aspergillus species. ${ }^{91}$}

Such a character suggests that the $A$. candidus enzyme may be different from the other Aspergillus proteinases, since the rate of migration in polyacrylamide gel electrophoresis is con- 
sidered to reflect the net charge, shape and size of an enzyme protein molecule.

Alkaline proteinase of $A$. candidus was purified to be homogeneous in ultracentrifugal and electrophoretic analyses by treatment of Amberlite IRC-50, chromatography on DEAE-cellulose and hydroxylapatite columns and gel filtration through Sephadex G-100 column. The behavior of the enzyme protein during the above purification procedure is very similar to that of the $A$. sojae enzyme. ${ }^{4 \prime}$

The sedimentation coefficient, $s_{20}^{\mathrm{W}}(3.0 \mathrm{~S})$ of the $A$. candidus enzyme, is consistent with that of $A$. sojae alkaline proteinase. ${ }^{10)}$ Moreover, the molecular weight $(23,000)$ of alkaline proteinase from $A$. candidus determined by gel filtration method is also in good agreement with those from $A$. sulphureus (M. W. 23,000) ${ }^{8}$ ) A. sojae (M. W. $23,000 \sim 24,000)^{18}$ and $A$. flavus (M. W. $19,500 \sim 22,000)^{5}$ but somewhat smaller than that from A. melleus (M. W. $27,900){ }^{6}{ }^{6}$ In spite of big difference in electrophoretic mobility, therefore, the molecular sizes of alkaline proteinases from Aspergillus species seem to be much alike.

The absence of both cysteine and cystine is noteworthy aspect in amino acid composition of the enzyme. This character is universal, so far studied, ${ }^{3,5,6,18,19}$ ) in all Aspergillus alkaline proteinases, since the presence of one cysteine residue in the $A$. sojae enzyme ${ }^{20 /}$ has been corrected by further investigation. ${ }^{18}$ On the other hand, two methionine residues are found in the $A$. candidus enzyme as in the $A$. sojae proteinase, although only one methionine residue is detected in the $A$. flavus enzyme ${ }^{5}$ and $A$. oryzae aspergillopeptidase $\mathrm{C}^{3}{ }^{3}$ To this contrary, the absence of methionine is reported in the $A$. sulphureus enzyme ${ }^{8)}$ and $A$. oryzae aspergillopeptidase $\mathrm{B}^{19}$, The content of the other amino acids is not so variable each other among the above enzymes.

Similarity of the enzymatic properties of fungal alkaline proteinases referred above may be expected by the close resemblance of the data of their molecular weights and amino acid patterns.

Acknowledgement. The authors wish to express their sincere thanks to Profs. K. Arima and Y. Ikeda, University of Tokyo, for their valuable suggestions and discussions and also to Drs. M. Mogi and N. Iguchi for their encouragement throughout this work.

\section{REFERENCES}

1) H. Matsubara and J. Feder, "The Enzymes," Vol. III, 3rd Ed., ed. by D. D. Boyer, Academic Press Inc., New York, 1971, p. 721.

2) A. R. Subramanian and G. Kalnitsky, Biochemistry, 3, 1861 (1964).

3) A. Nordwig and W. F. Jahn, Europ. J. Biochem., 3, 519 (1968).

4) K. Hayashi, D. Fukushima and K. Mogi, Agr. Biol. Chem., 31, 1171 (1967).

5) J. Turková, O. Mikeš, K. Gančev and M. Boublik, Biochim. Biophys. Acta, 178, 100 (1969).

6) M. Ito and M. Sugiura, Yakugaku Zasshi, 88, $1576(1968)$.

7) G. Danno and S. Yoshimura, Agr. Biol. Chem., 31, 1151 (1967).

8) G. Danno, ibid., 34, 264 (1970).

9) S. Nasuno, ibid., 35, 1147 (1971).

10) S. Nasuno and T. Ohara, ibid., 35, 836 (1971).

11) M. L. Anson, J. Gen. Physiol,, 22, 79 (1938).

12) H. K. Schackman, "Methods in Enzymology," ed. by S. P. Colowick and N. O. Kaplan, Vol. IV, Academic Press Inc., New York, 1957, p. 32.

13) B. J. Davis, Ann. N. Y. Acad. Sci., 121, 404 (1964).

14) T. W. Goodwin and R. A. Morton, Biochem. J., 40, 628 (1946).

15) E. J. Conway, "Micro-diffusion Analysis and Volumetric Error," 3rd Ed., Crosby Lockwood and Son, London, 1950.

16) K. Bailey, Biochem. J., 31, 1406 (1937).

17) J. R. Whitaker, Anal. Chem., 35, 1950 (1963).

18) K. Hayashi, M. Terada, D. Fukushima and K. Mogi, Chomi Kagaku (Seasoning Science), 17, 170 (1970).

19) A. R. Subramanian and G. Kalnitsky, Biochemistry, 3, 1868 (1964).

20) K. Hayashi, D. Fukushima and K. Mogi, Agr. Biol. Chem., 31, 1237 (1967). 